ISSN: $1984-2201$

Copyright @ 2002, Universidade Federal do Ceará

\title{
GEOMORPHOLOGICAL APPROACH IN THE STUDY OF MINING HERITAGE
}

\author{
VON AHN, Mauricio Mendes ${ }^{a *}$ SIMON, Adriano Luis Heck ${ }^{\text {* }}$
}

(a) Master in Geography. Federal University of Pelotas (UFPEL), Passo Fundo (RS), Brazil. ORCID ID: https://orcid.org/0000-0001-8442-2056. CURRICULUM LATTES: http://lattes.cnpq.br/6786074629426102

(b) Doctor in Geography. Professor Federal University of Pelotas (UFPEL), Passo Fundo (RS), Brazil. ORCID ID: https://orcid.org/0000-00032888-308X. CURRICULUM LATTES: http://lattes.cnpq.br/0532593883570233

\section{(*) CORRESPONDING AUTHOR}

Address: UFPEL - Rua Coronel Alberto Rosa, n. 154, sala 105. Pelotas (RS). CEP: 96010770 . (+55 55) 5332845500 (r. 212 ).

E-mail: adriano.simon@ufpel.edu.br

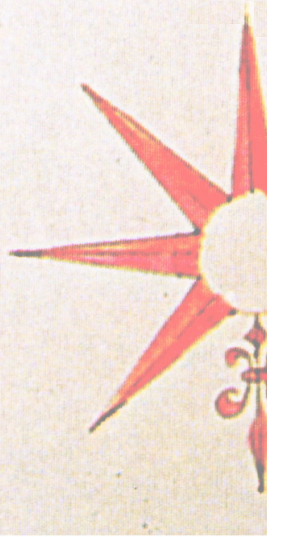

\begin{abstract}
The objective of this work is to analyze the potential of the anthropogenic relief as an unexplored dimension of mining heritage, since it understands that the geomorphological features derived from the mineral extraction process have value for geoconservation actions. A survey and analysis of bibliographical references was carried out to identify the articulation between mining and geoconservation, from a geomorphological approach. Finally, a conjunctural analysis was proposed in the Minas do Camaquã Geosite, in order to understand the anthropogenic forms of relief as mining heritage. Anthropogenic morphologies derived from mining activities should be explored based on their relationship with the techniques used for their spatial organization and the historical period in which they were created and may promote geotourism geared towards mining in geosites occurring in mining areas.
\end{abstract}

Keywords: Mining; Anthropogenic relief; Geoconservation.

\section{RESUMO / RESUMEN}

\section{ABORDAGEM GEOMORFOLÓGICA NO ESTUDO DO PATRIMÔNIO MINEIRO}

O trabalho tem como objetivo analisar o potencial do relevo antropogênico enquanto dimensão ainda pouco explorada do patrimônio mineiro, pois compreende que as feições geomorfológicas oriundas do processo de extração mineral possuem valor para ações de geoconservação. Foi realizado o levantamento e análise de referências bibliográficas que possibilitaram identificar a articulação entre mineração e geoconservação, a partir de uma abordagem geomorfológica. Ao final foi proposta uma análise conjuntural no Geossítio Minas do Camaquã, a fim de compreender as formas do relevo antropogênicas enquanto patrimônio mineiro. As morfologias antropogênicas derivadas das atividades de mineração devem ser exploradas a partir da relação das mesmas com as técnicas utilizadas para sua organização espacial e o período histórico em que foram criadas, podendo promover o geoturismo voltado à exploração do patrimônio mineiro em geossítios com ocorrência em área de mineração.

Palavras chaves: Mineração; Relevo antropogênico; Geoconservação.

\section{ENFOQUE GEOMORFOLÓGICO EN EL ESTUDIO DEL PATRIMONIO MINERO}

El trabajo tiene como objetivo analizar el potencial del relieve antropogénico como dimensión aún poco explorada del patrimonio minero, pues comprende que las características geomorfológicas oriundas del proceso de extracción mineral poseen valor para acciones de geoconservación. Se realizó el levantamiento y análisis de referencias bibliográficas que posibilitaron identificar la articulación entre minería y geoconservación, a partir de un enfoque geomorfológico. Al final se propuso un análisis coyuntural en el Geossítio Minas do Camaquã, a fin de comprender las formas del relieve antropogénico como patrimonio minero. Las morfologías antropogénicas derivadas de las actividades de minería deben ser exploradas a partir de la relación de las mismas con las técnicas utilizadas para su organización espacial y el período histórico en que fueron creadas, pudiendo promover el geoturismo volcado a la explotación del patrimonio minero en geositios con ocurrencia en área de minería.

Palabras clave: Minería; Relieve antropogénico; Geoconservación. 


\section{INTRODUCTION}

On the whole, mining activities are generally associated with conflictual relationships with geoconservation practices (GESICKI and SANTUCCI, 2011, BRILA, 2014), but they can be reconciled (DAVID and KARANCSI, 2010; BADERA et al., 2011; CONLIN and JOLLIFFE, 2011; LÓPEZ-GARCIA et al., 2011; GESICKI and SANTUCCI, 2011; HORVÁTH and CSÜLLÖG, 2012; BRILHA 2014; DIAS, 2015).

Mining activities follow the evolution of civilizations, with increasing amounts of these resources being mobilized to meet socioeconomic demands (HOOCK, 2000; DÁ VID, 2010; PRICE, 2011). Geoconservation emerged at the end of the twentieth century, with the objective of ensuring "the conservation of geodiversity for its intrinsic ecological and geo-patrimonial values" (SHARPLES, 2002). According to Brilha (2014), geoconservation does not intend to extinguish or threaten mining activities, since modern society needs mineral resources to maintain the demand for consumer goods. For the author, geoconservation aims to preserve the most significant vestiges of the Earth's long history for society's use, mainly from a scientific and educational point of view, including mining areas.

López-García et al. (2011) state that mining areas make it possible to understand the magnitude of man's action on geodiversity. Changes occur in the geology and geomorphology of these spaces leading to the organization of anthropogenic landscapes also recognized as geoheritage, and, therefore, susceptible to geoconservation actions. The anthropogenic features in mining areas also subsidize explanations about the history of the Earth in a recent period where geological and historical (human) time scales overlap, creating Anthropocene forms and processes (ZALASIEWICZ et al., 2008).

At the end of the twentieth century, the concept of mining heritage (PUCHERIART et al., 1994, VERDE and PICÓN, 2010, IGME, 2012, MÁRCHAN and SÁNCHEZ, BRILHA, 2014) revealed an approximation between mining activities and geoconservation, with anthropogenic relief as one possible approach. The organization of the anthropogenic relief in mining areas is the starting point for the constitution of the other elements belonging to mining heritage, such as industrial facilities and architectural structures, and therefore deserves prominence as a constituent element of this patrimony.

In view of these initial considerations, this work was developed with the objective of analyzing the potential of the anthropogenic relief as an unexplored dimension of mineral heritage, in order to show that geomorphological features from the mineral extraction process have value for geoconservation actions in areas under strong mining influence.

To develop this research works were analyzed that made it possible to identify the relationship between mining and geoconservation in areas of open-cast mineral exploration, where the anthropogenic relief has a strong geotouristic potential and could be exploited as mining heritage.

The references were selected from online databases such as: the digital libraries of Brazilian and international universities (Federal University of Rio Grande do Sul, University of São Paulo, Paulista State University, Federal University of Rio de Janeiro, University of Minho, University of Coimbra and University of Porto); the Brazilian Digital Library of Theses and Dissertations (BDTD); Web of Science; the CAPES / MEC Portal of Journals; the Brazilian Commission of Geological and Paleobiological Sites (SIGEP); the Geological Survey of Brazil (CPRM) and the Scientific Electronic Library Online (SCIELO).

The search methodology for the references obeyed two criteria and filters, applied in all the online databases: keywords and languages. Six key words were defined: mining; geoconservation; mining heritage; geotourism; anthropogeomorphology; and geosites in mining areas. The search for the keywords occurred in a combined way, in English, Portuguese and Spanish. 
The initial search found 92 bibliographic references, of which 32 were effectively selected after an analysis of the abstracts, objectives and methodology. Among the selected references, 20 approach concepts related to Mining, Geoconservation and Mining Heritage, 7 refer to concepts linked to Geodiversity, Geoconservation and Geotourism, and 5 are related to the concept of Anthropogenic Geomorphology.

The search and revision of these works began in July 2015 and lasted until March 2016. At the end of the review, a conjunctural analysis was proposed at the Minas do Camaquã Geosite (Rio Grande do Sul state, Brazil), in order to relate the anthropogenic forms of the relief to the mineral heritage originating from a historical occupation process linked to the mineral exploration of copper.

\section{MINING AND GEOCONSERVATION: MINING HERITAGE AS A POSSIBILITY}

At the Rio +10 Conference in 2002, mining was considered as a fundamental activity for economic and social development (DIAS, 2015). However, Brilha (2014) emphasizes that mining activity can lead to the destruction of geological features that have potential scientific, educational and touristic uses.

According to López-García et al. (2011), mining can promote geoconservation, since in some situations, it allows access to rocky massifs where new geological occurrences with geo-patrimonial relevance are identified (BRILHA, 2014), revealing important questions regarding the Earth's evolutionary memory (DIAS, 2015).

Mining areas have natural and cultural elements that can provide the basis for the development of tourism (HORVÁTH and CSÜLLÖG, 2012), and many mines have a cultural and industrial heritage that is part of the geoheritage (DAVID and KARANCSI, 2010; JOLLIFFE, 2011). According to the cited authors the number of tourists interested in visiting regions whose landscape is expressed by the heritage of mining is increasing.

For Nascimento et al. (2013), a mine exposes the geological heritage of a region as few points on the planet can and keeps all the memory of the techniques and difficulties of the peoples involved and the way resources are appropriated, implying the existence of immaterial and material patrimony.

López-García et al. (2011) explain that abandoned mining areas that have sufficient educational, cultural, historical or scientific value should be prioritized by geoconservation actions and should be recognized as geosites. According to Horváth and Csüllög (2012), even though there are a significant number of abandoned mines and quarries capable of geoconservation actions, it is difficult to find sites under the influence of mining that are recognized as geosites.

The first group interested in the conservation of the mining memory was formed in the region of Cornwall, South-West England, with the creation of the Cornish Engineer's Preservation Committee in 1935, aimed at the conservation of the local mine buildings (PUCHERIART, 2000). Brilha (2014) considers that mining heritage refers to everything that is involved in the exploitation of active and / or inactive mining, such as minerals and rocks that are being (or have been) extracted from the subsoil, industrial facilities, historical documentation of the mines, processes and techniques of exploration, and even the histories and traditions of mining communities.

Márchan and Sánchez (2013) explain that mining heritage also includes the cultural landscapes resulting from the open-cast and underground excavation fronts. These cultural landscapes encompass man-made relief forms in mining areas and studied by anthropogenic geomorphology. 


\section{ANTHROPOGENIC RELIEF AND MINING HERITAGE: THE EXAMPLE OF THE MINAS DO CAMAQUÃ GEOSITE (BRAZIL)}

Anthropic action acts directly as a geomorphological agent in mining areas, as it uses techniques that alter the drainage network and relief to exploit ore (SZABÓ, 2010). According to Puche Riart et al. (1994), Fagiewicz (2009) and Badera et al. (2011) especially in the case of open-cast mines, the relief is remodeled in such a way that new morphologies of great interest and landscape, technical-scientific, cultural and tourist value are created.

According to Verde and Pincón (2010) the other structures created as a result of mining activities (villages, industrial structure and processing) reinforce the importance of the anthropogenic relief as an initial milestone in the constitution of the mining heritage. Verde and Pincón (2010) also state that there are different specialties that study mining heritage, including architects, engineers, geologists, historians, economists, geographers, anthropologists and sociologists. However, the geomorphological dimension is little explored when considering the fact that interventions in the relief in mining areas are considerable and that the record of these interventions remains imprinted in the landscape of regions under the influence of active and / or inactive mining activities.

Thus, geomorphological knowledge must subsidize the evaluation of and value given to the mining heritage of geosites. Carton et al. (2005) propose that this subsidy should occur from the elaboration of geomorphological maps that allow an immediate perception of the spatial distribution of relief forms, both to technical personnel and the population in general. The aforementioned authors affirm that the cartographic representation of geosites showing the anthropogenic relief is underexplored, although it is relevant for future geotourism actions.

Hose (2000) defines geotourism as the incentive of interpretive means and services to spread the value and social benefits of geological and geomorphological sites and materials, ensuring their conservation, for the use of students and tourists. Thus, geotourism aims to disclose the geodiversity of a given region and, depending on the access conditions, become an economically viable activity (JUNIOR, 2013, VERAS, 2014).

Garofano and Govoni (2012) evidence the high potential of mining areas for geotourism activities that enable the understanding of aspects of anthropogenic relief, such as the history and techniques involved in its evolution over time.

In Brazil, the inventory and dissemination of geosites, proposed by the Geological and Paleobiological Sites Project - SIGEP, and the Brazilian Geoparks Program, linked to the Brazilian Geological Survey (CPRM), cover geosites in open-cast mining areas. This conjuncture paves the way for geomorphological studies that recognize, characterize, analyze and promote the anthropogenic relief associated with this mining heritage. The Minas do Camaquã Geosite (Rio Grande do Sul State, Brazil) is recognized for its geoheritage linked to mining activities and the anthropogenic relief is one of the most striking aspects of the landscape (BORBA, 2013).

The protection area of the Minas do Camaquã Geosite was defined and is located in the municipal boundaries of Caçapava do Sul, Santana da Boa Vista, Bagé and Pinheiro Machado, in the central region of the State of Rio Grande do Sul - Brazil ( Figure 1). The boundary of the Minas do Camaquã Geosite Protection Area (APGMC) was based on the studies of Borba (2013), who carried out an inventory of 46 geosites in the municipality of Caçapava do Sul, covering the Minas dos Camaquã geosite, defined by author as a place of conflict between its geopolitical importance and the extraction of ores, which results in its need for greater protection. 


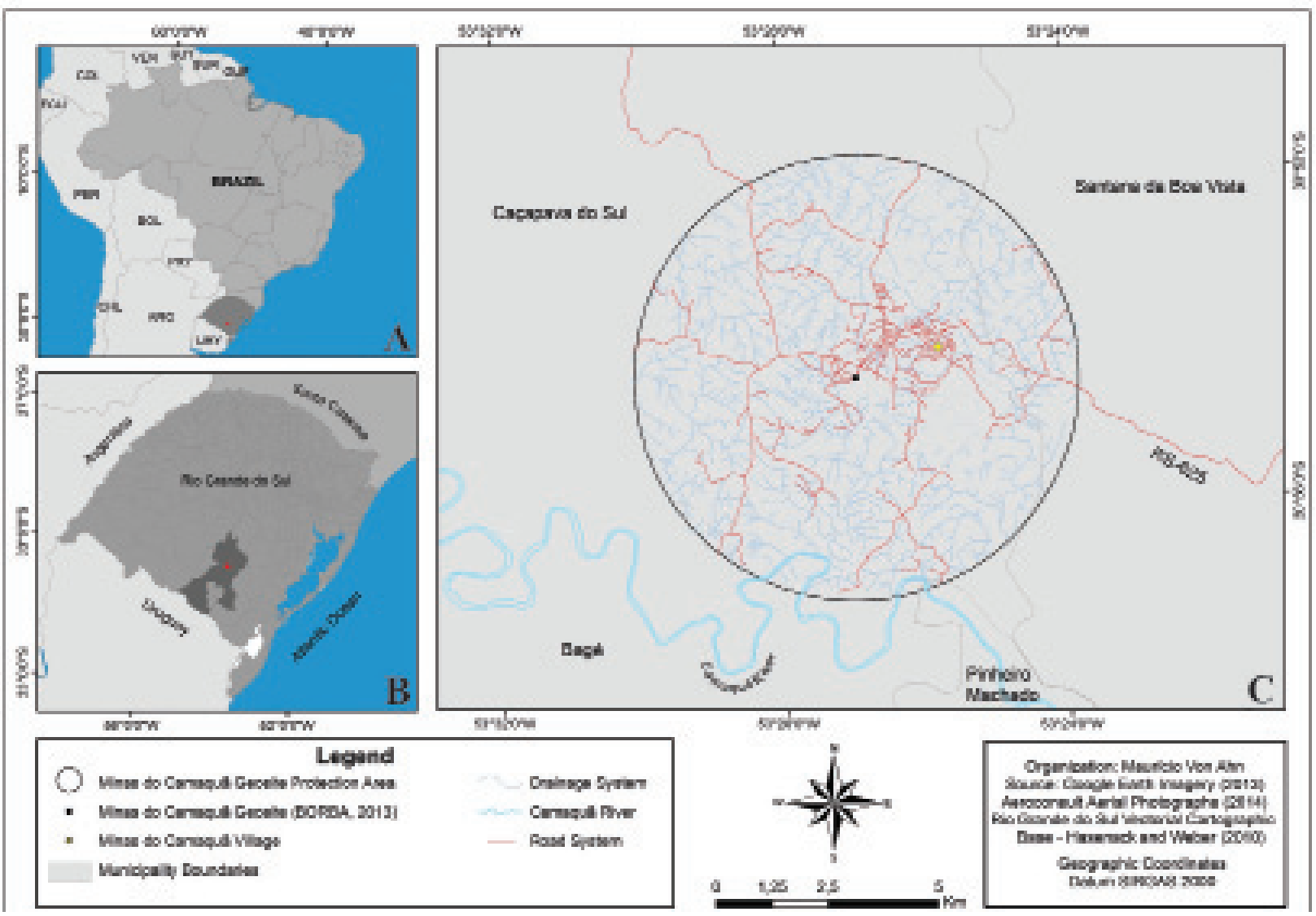

Figure 1- Location map of the APGMC. A - Map of Brazil with emphasis on the state of Rio Grande do Sul; B - Map of the state of Rio Grande do Sul with municipalities covering the protection area of the Minas do Camaquã geosite; C - Map of the protection area of the Minas do Camaquã geosite.

The extraction of copper at the Camaquã Mines began in mid-1865 (TEIXEIRA, 1992; PAIM, 2000) and contributed to the socio-spatial formation of the region until 1996, when the known reserves were fully depleted (PAIM, 2000, 2002). The intervention caused by mining has registered a set of anthropogenic morphologies in the landscape that are of great importance as elements associated to the mining heritage.

Figure 2 shows the anthropogenic relief resulting from the process of excavation and disposal. We highlight the abrupt levels in inactive mining pits, with the occurrence of an artificial lake. These morphologies have different potentials and limitations for use in geotourism (Figure 2). 


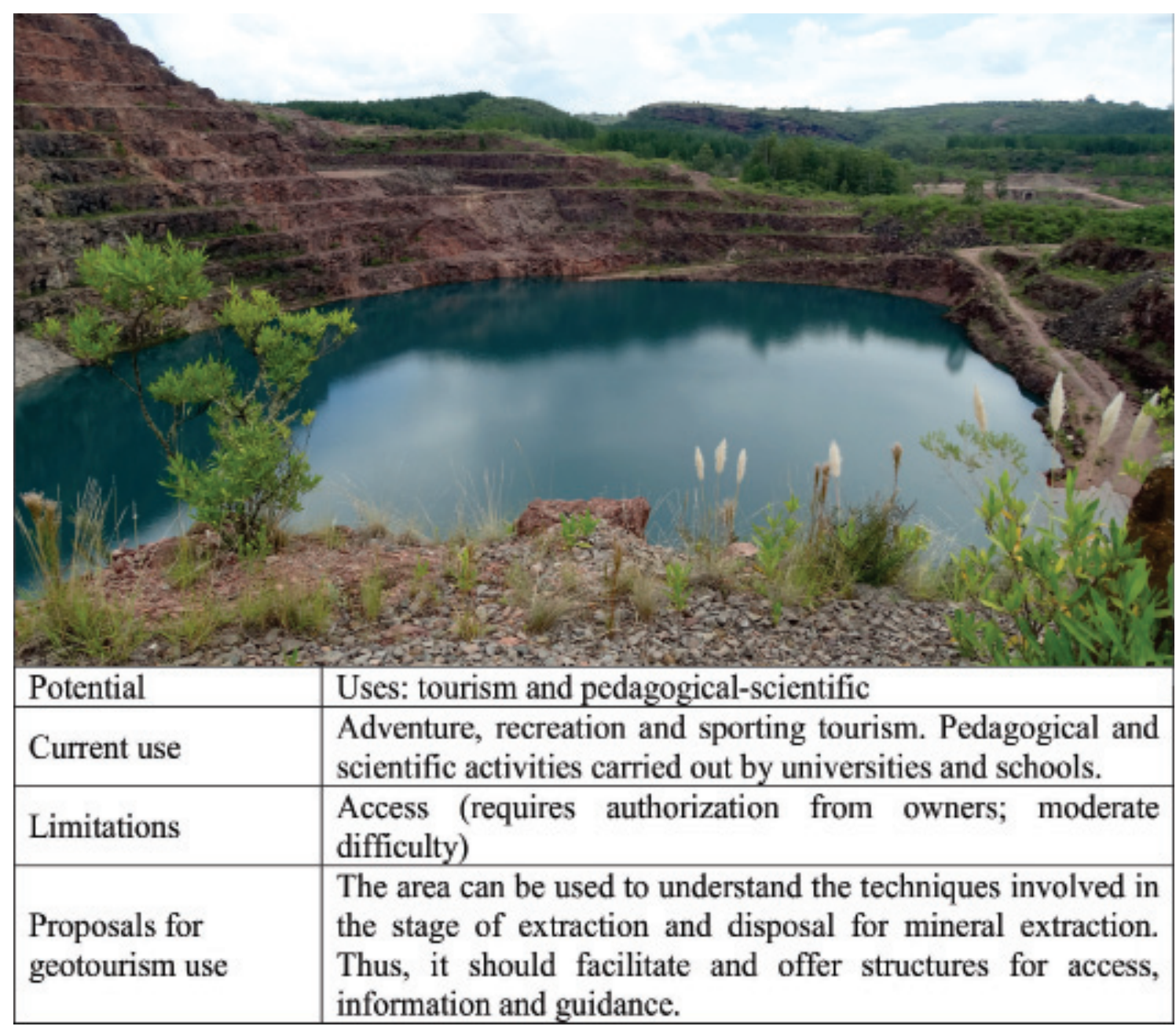

Figure 2 -Potential evaluation for the geotouristic use of the anthropogenic morphologies derived from the excavation or disposal stage.

The exploitation of the anthropogenic relief is already taking place in this area from activities directed to adventure tourism, such as guided trails, zipline, rowing, canopy, abseiling, kayak, hiking, mountain biking and cycling, quadricycles, riding, climbing wall, among others (Figure 3). However, the current adventure tourism does not provide an interpretation of the local geological-geomorphological context. Therefore, activities that propose an association between adventure tourism and geotourism are needed to enable a better understanding of the mining heritage present in the region.

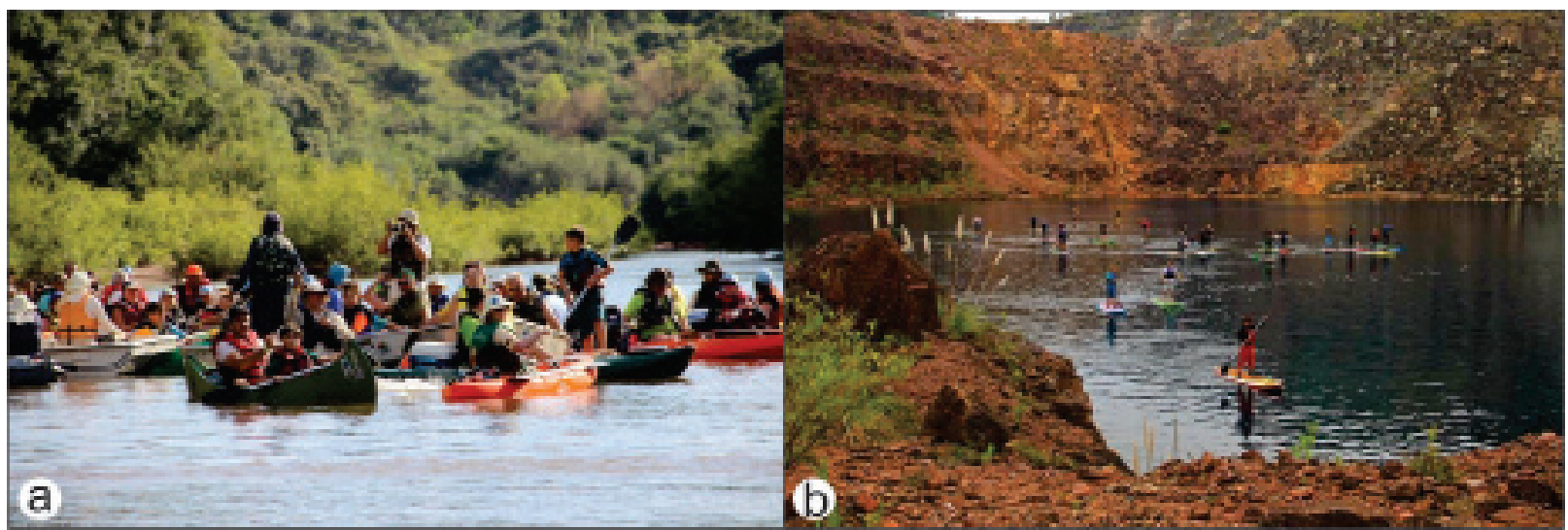

Figure 3 - Figure 3a: kayaking at the Arroio João Dias dam, built in the twentieth century to provide power for the mining enterprise. In Figure 3b: Stand Up Paddle on the lake located in one of the open-cast mines.

Source: Minas Outdoor Sports 
According to Brilha (2014), agreements with the owners of mines, quarries and mining companies can be the gateway to geoconservation and geotourism actions. The author also emphasizes that inactive mining areas, as well as those that do not have high economic income, must be made available by their owners for studies and activities with scientific, educational and tourist purposes.

Figure 4 shows the morphologies resulting from the process of loading and transporting the material resulting from the excavation and disposal. These forms were created to provide access to the mines, leading to cuttings, landfills, embankments and conduits for roadways.

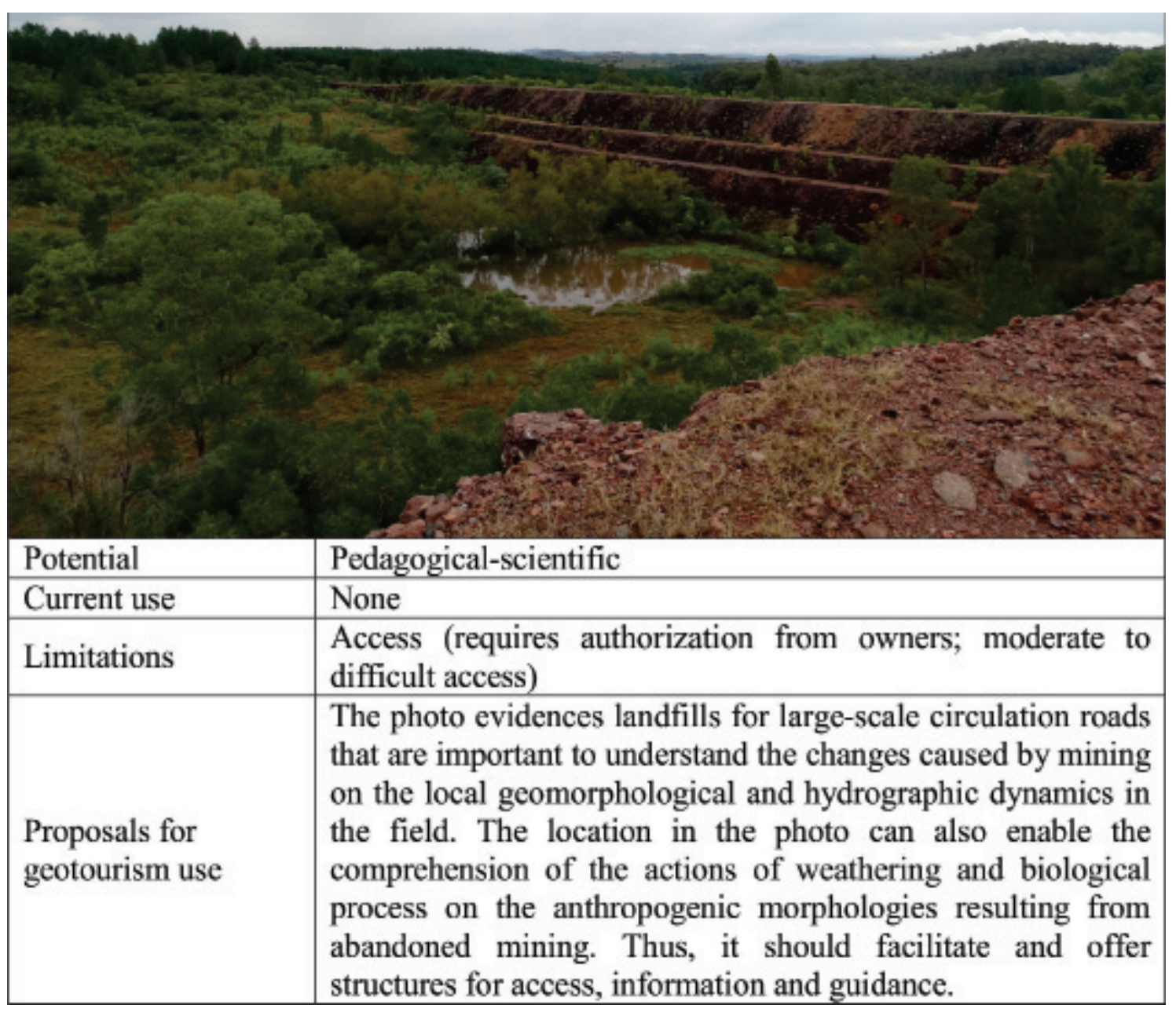

Figure 4 - Potential evaluation for the geotouristic use of the anthropogenic morphologies created from the loading and transport stage.

Figure 5 makes it possible to identify the anthropogenic morphologies resulting from the disposal process in sterile piles. The deposition of the sterile cells gave rise to morphologies recognized as sterile hill borders and sterile hill slopes. 


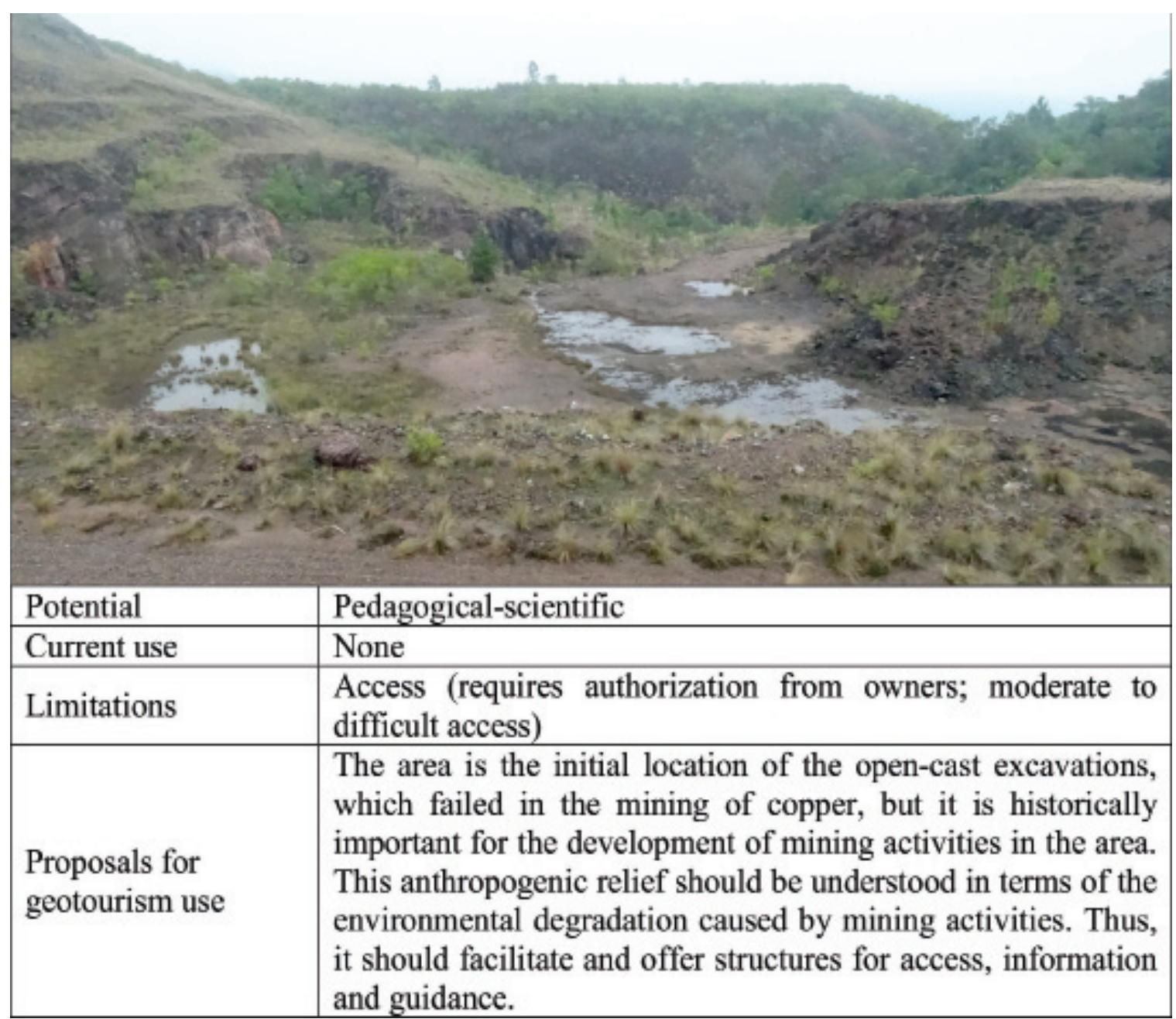

Figure 5 - Evaluation of the potential for the geotouristic use of the anthropogenic features from the disposal stage in sterile piles.

The three examples show that access to the mining heritage in question is still one of the main limitations for the best tourist and pedagogic-scientific use of anthropogenic morphologies. Access involves the owners' permission and the best indication regarding the safest places for satisfactory observation conditions.

With the exception of the lake in the mining pit, the other morphologies are underutilized. Proposals for geotourism should be based on the organization of itineraries, with the support of interpretive panels that invite visitors to understand the landscape they are contemplating, based on the understanding of visual and textual elements in an accessible language.

\section{FINAL CONSIDERATIONS}

Based on the theoretical review and the conjunctural analysis, some final considerations were developed:

(1) Anthropogenic forms must be exploited from their relationship with the techniques used for their spatial organization and the historical period in which they were created. This reveals the magnitude of anthropic interference in the natural landscape and shows the complexity involved in the mining stages that have led to the constitution of features with significant potential as mining heritage. 
(2) The anthropogenic relief impressed on the landscape must be explored by geotourism in order to enable tourists, researchers, school and university students and other interested persons to immerse themselves in the history of the activities that occurred over a short period of time and led to the creation of these anthropogenic forms.

(3) The anthropogenic relief must subsidize geotourism geared towards the exploration of the mining heritage of geosites in mining areas. The involvement of the local population is important because it facilitates the diffusion of knowledge about mining activities.

(4) The anthropogenic features present in the Minas do Camaquã Geosite reveal the history of the mining activities that occurred in the area and are of geographical importance. These features should be understood as a mining heritage that qualifies Minas do Camaquã Geosite as a mining history geosite.

\section{BIBLIOGRAPHIC REFERENCE}

BADERA, J.; RAHMONOV, O.; TOMASZ, P. The quarry in Kozy as a geotourist attraction and the object of natural and cultural heritage in the context of sustainable development. Geotourism, v. 3, n. 26, p. 41-50, 2011.

BORBA, A. W.; SOUZA, L. F.; MIZUSAKI, A. M. P.; ALMEIDA, D. M.; STUMPF, P. P. Inventário e avaliação quantitativa de geossítios: exemplo de aplicação ao patrimônio geológico do município de Caçapava do Sul (RS, Brasil). Pesquisas em Geociências, v. 40, n.3, p. 275-294, 2013.

BRILHA, J. Mining and Geoconservation. Encyclopedia of Mineral and Energy Policy, v.9, n. 1, p. 1-2, 2014. CARTON, A.; CORATZA, P.; MARCHETTI, M. Propositions pour la cartographie des sites géomorphologiques: exemples italiens. Revue du Groupe Français de Géomorphologie, n. 3, p. 209-218, 2005.

CONLIN, M.; JOLLIFFE, L. Mining heritage and tourism. New York: Routledge, 2011. 247p.

DÁVID, L.; KARANCSI, Z. Quarrying, geoheritages and tourism development in the Medves region along the Hungarian-Slovakian border. Acta Geoturistica, v. 1, n. 1, p. 1-11, 2010.

DÁVID, L. Quarrying and Other Minerals. In: SZABÓ, J.; LÓRANT, D.; LÓCZY, D. (Org.) Anthropogenic Geomorphology. London: Springer, 2010. p. 113 -130.

DIAS, L. C. Conflitos e possibilidades entre atividade minerária e geoconservação na área do Geoparque Costões e Lagunas - RJ. 2015. 153f. Dissertação (Mestrado em Geociências e Meio Ambiente) - Universidade Estadual Paulista, Rio Claro, 2015.

FAGIEWICZ, K. Obszary pogórnicze jako typ krajobrazu recepcyjnego turystyki. Problemy Ekologii Krajobrazu, v. 25, pp. 95-103, 2009.

GAROFANO, M.; GOVONI, D. Underground Geotourism: a Historic and Economic Overview of Show Caves and Show Mines in Italy. Geoheritage, v. 4, pp. 79-92, 2012.

GESICKI, A. L. D.; SANTUCCI, R. M. Mineração e Geoconservação: o Sítio Paleontológico de Santa Rosa de Viterbo, SP. Revista do Instituto Geológico, v. 32, n. 1/2, p. 41-53, 2011.

HOOCK, R. L. On the history of humans as geomorphic agents. Geology, v. 28, n. 9, p. 843-846, 2000.

HORVÁTH, G.; CSÜLLÖG, G. The Role of Ecotourism and Geoheritage in the Spatial Development of Former Mining Regions. In: WIRTH, P.; CERNIC, M.; FISCHER, W. (Eds.) Post-Mining Regions in Central Europe - Problems, Potentials, Possibilities. München: Oekom, 2012. p. 226-240.

HOSE, T. Geoturismo europeo: Interpretación geológica y promoción de La conservación geológica para turistas. In: BARRETINO, W. A. P.; GALlEGO, E. (Org.) Patrimonio geológico. Madrid: Instituto Tecnológico Geominero de España, 2000. p. 137-159.

JUNIOR, E. D. S. Levantamento do potencial geoturístico do Parque Nacional do Catimbau - PE como subsídio para criação de um futuro Geoparque. 2013. 90f. Dissertação (Mestrado em Geografia) -Universidade Federal de Pernambuco, Recife, 2013. 
LÓPEZ-GARCIA, J. A.; OYARZUN, R.; ANDRÉS, S. L.; MARTÍNEZ, J. I. M. Scientific, Educational, and Environmental Considerations Regarding Mine Sites and Geoheritage: A Perspective from SE Spain. Geoheritage, v. 3, pp. 267-275, 2011.

MARCHÁN, C.; SÁNCHEZ, A. Consideraciones sobre el patrimônio minero desde la perspectiva de um serviço geológico nacional. Boletim paranaense de Geociências, v. 70, pp. 77-86, 2013.

NASCIMENTO, M. A. L.; ROCHA, A. J. D.; NOLASCO, M. C. Patrimônio geológico e mineiro no nordeste do Brasil. Boletim paranaense de geociências, v. 70, pp. 103-119, 2013.

PAIM, Paulo Sérgio Gomes.; LOPES, Ricardo Cunha. Geologia da Região das Minas do Camaquã. In: RONCHI, L. H.; LOBATO, O. C (Org.) Minas do Camaquã, um estudo multidisciplinar. São Leopoldo: Unisinos, 2000. p. 111-132.

PAIM, Paulo Sérgio Gomes. Minas do Camaquã, RS-Marco da história da mineração de cobre no Brasil. In: SCHOBBENHAUS, C.; CAMPOS, D.; QUEIROZ, E.; WINGE, M.; BERBERT-BORN, L. (Eds.) Sítios Geológicos e Paleontológicos do Brasil. Brasília: Comissão Brasileira de Sítios Geológicos e Paleobiológicos, 2002. p. 501-510.

PRICE, S. J.; FORD, J. R.; COOPER, A. H.; NEAL, C. Humans as major geological and geomorphological agents in the Anthropocene: the significance of artificial ground in Great Britain. Philosophical Transactions of the Royal Society of London A, v. 369, pp. 1056-1084, 2011.

PUCHERIART, O.; GARCÍA-CORTÉZ, A.; PERELLO, J. M. M. Conservación Del Patrimonio Histórico Minero-Metalúrgico español. Anais do IX Congresso Internacional de Minería y Metalurgia, León, 1994.

PUCHERIART, Octavio. La conservación del patrimônio geológico y minero. In: GIMENA, E. C.; RODRÍGUEZ, A. H. (Eds.) Ciento cincuentaaños: 1849-1999. Madrid: IGME, 200. p. 73-101.

SHARPLES, C. Concepts and principles of geoconservation. Tasmanian, Australia: Parks and Wildlife Service, 2002. 86p.

SZABÓ, József. Anthropogenic Geomorphology: Subject and System. In: SZABÓ, J.; LÓRANT, D.; LÓCZY, D. (Org.) Anthropogenic Geomorphology. London: Springer, 2010. p. 3-10.

TEIXEIRA, E. Lavras do Sul, na bateia do tempo. Santa Maria: Editora da Universidade Federal de Santa Maria, 1992. 87p.

VERAS, A. S. S. A paisagem como recurso e o geoturismo como possibilidade em Mucajaí-RR. 2014. 134f. Dissertação (Mestrado em Geografia) - Universidade Federal de Roraima, Boa Vista, 2014.

VERDE, M. A. P.; PICÓN, A. S. Patrimonio minero: um variopinto y problemático mundo de vestígios. Revista Internacional de Ciências Sociais, v. 29, pp. 51-60, 2010.

ZALASIEWICZ, J.; WILLIANS, M. Are we now living in the Anthropocene? GSA Today, v. 18, n. 2, p. 4-8, 2008. 